\title{
Estimation Of The Preliminary Screening of Phytochemicals, Total Phenolic Content, Total Flavonoid Content, Antioxidant And Alpha-Amylase Inhibitory Activities Of The Selected South African Plant Extracts For Medicinal Purposes.
}

\author{
Nkala, B.A, ${ }^{1}, *$, Mbongwa, H.P. ${ }^{1}$, Qwebani-Ogunleye, T $^{2}$ \\ ${ }^{1}$ Department of Human Physiology, School of Laboratory Medicine and Medical Sciences, College of Health Sciences, University of KwaZulu- \\ Natal, Durban, 4001, South Africa \\ ${ }^{2}$ Institute of Traditional Medicine and Traditional Knowledge, Vaal University of Technology Science and Technology Park, 5 Moshoeshoe Road, \\ Sebokeng, 1911, South Africa.
}

DOI: 10.29322/IJSRP.11.10.2021.p11822

http://dx.doi.org/10.29322/IJSRP.11.10.2021.p11822

\begin{abstract}
Medicinal plants serve as important sources of pharmaceutical, cosmetic and traditional medicine. Natural products continue to play a significant role in drug discovery and development. Bioactive compounds, which naturally occurs in medicinal plants, such as antioxidants, play a vital role in scavenging free radicals. The purpose of this study was to evaluate preliminary phytochemicals, total phenolic content, total flavonoid content, antioxidants, and alpha $(\alpha)$-amylase potential on selected South African plant extracts.

In qualitative analysis, the phytochemical compounds such as tannins, saponins, flavonoids, quinones, phenols, terpenoids, alkaloids, glycosides, cardio glycosides, coumarins, betacyanin, Anthocyanin, and Steroids were screened and quantified. In addition to this, antioxidants were analysed using DPPH and ABTS radical scavenging assays. Out of thirteen qualitative phytochemicals analyzed, ten phytochemicals were identified. The antioxidant inhibition was observed in four plant species whose scavenging activity was above $80 \%$ are Schubria pinnata>Lippia javanica $>$ Clerodendrum myricoides $>$ Erythrina lysistemon $>$ respectively. Also, these plant species exhibited an alphaamylase inhibitory effect of $80 \%$. The $\mathrm{IC}_{50}$ values were $>1000 \mu \mathrm{g} / \mathrm{ml}$. These findings suggest that the presence of phenolic, flavonoids, antioxidants, and $\alpha$-amylase properties are potential solutions towards the management of diabetes and other chronic inflammatory diseases.
\end{abstract}

Index Terms- phytochemicals, phenolic, flavonoid, antioxidants, alpha-amylase, medicinal plants.

\section{INTRODUCTION}

$\mathrm{P}$ hytochemicals are chemicals produced by plants either through primary or secondary metabolism (Kennedy and Wightman, 2011). In general, phytochemicals play an important role in protecting plant growth or act as a defence against competitors, pathogens, or predators (Saxena et al., 2013). Importantly, phytochemicals have been reported to protect humans against diseases (Roa, 2003). The protective role of secondary metabolites extends to antioxidants free radical-scavenging, UV light-absorbing, antimicrobial, and anti-proliferative agents (Saxena et al., 2013, Wink, 2003, Kurutas, 2016). Antioxidants have also been defined as chemical substances that protect the body cells from injury by free radicals (Lobo et al., 2010). As delineated by (Knight, 1995, Lobo, 2010), free radicals attribute to more than one hundred disorders in humans, including atherosclerosis, arthritis, ischemia-reperfusion injury of many tissues, central nervous system injury, gastritis, and cancer. Furthermore, the protective effects from antioxidants have been observed to be useful towards the prevention of lipids damage, protein, and DNA using preventing radicals initiation, breaking chain propagation or suppressing formation (Kurutas, 2016). Moreover, these antioxidants can prevent deteriorating diseases such as cancer, and also slow down the ageing process (Bahiense et al., 2017, Kada et $a l .$, 2017). These metabolites are essentially used in traditional medicine to treat and manage certain diseases (Boadu and Asase, 2017).

The phytochemicals that are extracted from plants have been classified into three major groups which are terpenoids, phenolic metabolites, and alkaloids (Harborne et al., 1999). Approximately 10, 000 phytochemicals have been identified thus far (Zhang et al., 2015). The most important of these phytochemicals are alkaloids, tannins, 
flavonoids, saponins, glycosides, and other phenolic compounds, due to their biological activities screened from medicinal plants thus far (Dluya et al., 2017, Ali, 2011, Bossou et al., 2013, Mladenka et al., 2018, Sayhan et al., 2017, War et al., 2012).

Essentially, very few of these medicinal plants have been explored for their phytochemicals, and pharmacological potential so the chance of finding plants with medicinal uses exist (Mgbeahuruike et al., 2017, Street and Prinsloo, 2013). Furthermore, bioactive compounds with anti-inflammatory, antioxidant and antidiabetic properties are potential solutions towards the management of diabetes, and other chronic inflammatory diseases (Huang et al., 2016). The free radicals are naturally formed in the body, and play a pivotal role in many normal cellular processes (Diplock et al., 1998, Valko et al., 2007). However, at high concentrations, the free radicals can be hazardous to the body and may damage all major components of cells, including DNA, proteins, and cell membranes (Phaniendra et al., 2015). The damage to cells caused by free radicals, especially the damage to DNA, may play a role in the development of cancer, neurodegenerative disorders, cardiovascular diseases, diabetes, and other chronic health conditions (Halliwell, 1994, Diplock et al., 1998, Valko et al., 2007). Africa is host to a large percentage of the global floral diversity (Aslan et al., 2013). Only a few of these plants have been explored for their pharmacological potential meaning most of these plants remain untapped, especially in the southern African region (Street and Prinsloo, 2013). Therefore, the purpose of this study was to evaluate preliminary phytochemicals, total phenolic content, total flavonoid content, antioxidants, and alpha $(\alpha)$-amylase potential on selected South African plant extracts.

\section{Materials and methods}

\subsection{Chemicals and reagents}

All the chemicals and reagents used in this study were of analytical grade; which were quercetin, gallic acid, ascorbic acid, aluminium chloride, sodium carbonate, sulphuric acid, ferric chloride, Fehling's A and B, Rutin, folin Cocteau reagent, dragendorff reagent 2,2-diphenyl-1-picryhydrazyl (DPPH), and 2, 2'-azinobis (3ethylbenzthiazoline-6-sulphonic acid (ABTS).

\subsection{Plant collection and extraction}

Plant species $(n=9)$ were collected from Walter Sisulu National Botanical Gardens in South Africa; in February 2017 (Table 1). The voucher specimen number is held at Walter Sisulu National Botanical Gardens herbarium. The plant material was air-dried in a well-ventilated room. After drying, the plants were grounded into a powder and stored away from light at room temperature.

Table 1: Accession numbers and voucher specimen numbers of the plant species used in this study.

\begin{tabular}{|c|c|c|c|c|c|}
\hline \multirow[t]{2}{*}{ NAME } & \multirow[t]{2}{*}{ FAMILY } & \multirow[t]{2}{*}{ PART } & \multirow{2}{*}{$\begin{array}{l}\text { Accession } \\
\text { nUMBER }\end{array}$} & \multicolumn{2}{|c|}{$\begin{array}{l}\text { VOUCHER OF SPECIMEN } \\
\text { COLLECTED }\end{array}$} \\
\hline & & & & Date & NUMBER \\
\hline Euclea crispa & Ebenaceae & Leaf & $24 / 1982$ & $11 / 10 / 1982$ & 24, Behr, C.M \\
\hline Euclea natalensis & Ebenaceae & Leaf & $178 / 1987$ & $10 / 6 / 1987$ & 479; Steel, B.S \\
\hline Schkuhria pinnata & Asteraceae & Leaf & N/A & N/A & N/A \\
\hline $\begin{array}{l}\text { Ziziphus } \\
\text { mucronata }\end{array}$ & Rhamnaceae & Leaf & $36 / 1982$ & $15 / 10 / 1982$ & 39; Behr, C.M \\
\hline $\begin{array}{l}\text { Ziziphus } \\
\text { mucronata }\end{array}$ & Rhamnaceae & Fruits & $36 / 1982$ & $15 / 10 / 1982$ & 39; Behr, C.M \\
\hline Lippia javanica & Verbenaceae & Leaf & $16 / 2014$ & $22 / 1 / 2014$ & 28; Kondlo, M \\
\hline $\begin{array}{l}\text { Vernonia } \\
\text { oligocephala }\end{array}$ & Asteraceae & Leaf & $268 / 2013$ & $12 / 05 / 2013$ & 29; Hankey, A.J \\
\hline $\begin{array}{l}\text { Clerodendrum } \\
\text { myricoides }\end{array}$ & Lamiaceae & Leaf & $11 / 1987$ & $2 / 2 / 1987$ & 367, Steel, B.S \\
\hline
\end{tabular}




\begin{tabular}{|l|l|l|l|l|l|}
\hline $\begin{array}{l}\text { Erythrina } \\
\text { lysistemon }\end{array}$ & Fabaceae & Leaf & $21 / 1982$ & $7 / 10 / 1982$ & $22 ;$ Behr, C.M \\
\hline
\end{tabular}

\subsection{Preparation of plant extracts}

The grounded plant extracts (leaves, and fruits) were extracted with $90 \%$ methanol $(1 \mathrm{~g} / 10 \mathrm{ml})$, and vigorously shaken for $3 \mathrm{~h}$. The crude extracts were filtered through Whatman No.1 filter paper and dried at room temperature under the stream of cold air. The crude extracts were reconstituted in a solvent of choice at a concentration of 10 $\mathrm{mg} / \mathrm{ml}$.

\subsection{Qualitative phytochemical tests \\ 1.4.1 Test for alkaloids}

A few drops of concentrated hydrochloric acid $(\mathrm{HCl})$ were added to $2 \mathrm{ml}$ of each plant extract solution in a test tube. Then, the dragendorff reagent was added to the solution. The formation of orange precipitation indicated the presence of alkaloids.

\subsubsection{Test for cardio glycosides}

Plant extract $(0.25 \mathrm{~g})$ was dissolved into $1 \mathrm{ml}$ methanol $(\mathrm{MeOH})$ into a test tube. Two $\mathrm{ml}$ of glacial acetic acid and a few drops of $5 \%$ ferric chloride were added. In addition to this, $1 \mathrm{ml}$ of concentrated sulphuric acid $\left(\mathrm{H}_{2} \mathrm{SO}_{4}\right)$ was carefully added on the side of the test tube. The formation of the brown ring at interface indicates the presence of cardio glycosides.

\subsubsection{Test for flavonoids}

Plant extract $(0.75 \mathrm{~g})$ was dissolved in $3 \mathrm{ml}$ of $\mathrm{MeOH}$ in a test tube. Four $\mathrm{ml}$ of $1 \mathrm{~N}$ sodium hydroxide $(\mathrm{NaOH})$ was added into the test tube. The formation of dark yellow colour was observed which indicated the presence of flavonoids.

\subsubsection{Test for phenols}

Plant extract $(0.25 \mathrm{~g})$ was dissolved into $1 \mathrm{ml} \mathrm{MeOH}$ into a test tube. Two $\mathrm{ml}$ of distilled water was added into a test tube followed by $0.5 \mathrm{ml}$ of sodium carbonate $\left(\mathrm{Na}_{2} \mathrm{CO}_{3}\right)$ and $0.5 \mathrm{ml}$ Folin Ciocalteuau's reagent. The formation of a blue/green colour indicates the presence of phenols.

\subsubsection{Test for saponins}

Plant extract $(0.5 \mathrm{~g})$ was dissolved into $2 \mathrm{ml}$ of boiling water in a test tube. This was allowed to cool, and shaken well to mix thoroughly. The presence of foam indicates the presence of saponins.

\subsubsection{Test for steroids}

Plant extract $(0.25 \mathrm{~g})$ was dissolved into $1 \mathrm{ml} \mathrm{MeOH}$ into a test tube. Two $\mathrm{ml}$ of chloroform was added followed by $1 \mathrm{ml}$ of $\mathrm{H}_{2} \mathrm{SO}_{4}$. The formation of the reddish-brown ring at interface indicates the presence of steroids.

\subsubsection{Test for tannins}

Plant extract $(0.25 \mathrm{~g})$ was dissolved into $1 \mathrm{ml} \mathrm{MeOH}$ into a test tube. Two $\mathrm{ml}$ of $10 \%$ ferric chloride $\left(\mathrm{FeCl}_{3}\right)$ was added into the test tube. The formation of dark blue or greenish-grey colouring indicates the presence of tannins.

\subsubsection{Test for anthocyanin and betacyanin}

Plant extract $(0.5 \mathrm{~g})$ was dissolved into $2 \mathrm{ml} \mathrm{MeOH}$ into a test tube. One $\mathrm{ml}$ of $2 \mathrm{~N} \mathrm{NaOH}$ was added and heated for $5 \mathrm{~min}$ at $100^{\circ} \mathrm{C}$. The formation of bluish-green colour indicates the presence of anthocyanin, and the formation of yellow colour indicates the presence of betacyanin.

\subsubsection{Test for coumarins}

Plant extract $(0.25 \mathrm{~g})$ was dissolved into $1 \mathrm{ml} \mathrm{MeOH}$ into a test tube. The test tube was covered with filter paper which was moistened with $1 \mathrm{ml} \mathrm{NaOH}$. The test was placed in boiling water for a few minutes. Then the filter paper was removed, and examined under the UV light for yellow fluorescence to indicate the presence of coumarins. 


\subsubsection{Test for carbohydrates (Fehling's Test)}

Plant extract $(0.5 \mathrm{~g})$ was dissolved into $2 \mathrm{ml}$ of methanol in a test tube. One $\mathrm{ml}$ of Fehling's $\mathrm{A}$ and $1 \mathrm{ml}$ of Fehling's B was added into the test tube. Test tubes were placed in a boiling water bath for a few minutes, and test tube content was mixed as they come to boing, and colour change and precipitate formation was observed. Formation of a yellow or brownish-red precipitate indicates the presence of reducing sugars.

\subsubsection{Test for quinones}

Pant extract $(0.25 \mathrm{~g})$ was dissolved into $1 \mathrm{ml} \mathrm{MeOH}$ into a test tube. One $\mathrm{ml}$ of concentrated $\mathrm{H}_{2} \mathrm{SO}_{4}$ was added into a test tube. The formation of red colour indicates the presence of quinones.

\subsubsection{Test for terpenoids}

Plant extract $(0.25 \mathrm{~g})$ was dissolved into $1 \mathrm{ml} \mathrm{MeOH}$ into a test tube. Two $\mathrm{ml}$ of chloroform was added into the test tube, and followed by $1.5 \mathrm{ml}$ concentrated $\mathrm{H}_{2} \mathrm{SO}_{4}$ was carefully added. The formation of reddish-brown colour at the interface indicates the presence of terpenoids.

\subsection{Determination of total phenolic content}

The total phenolic content was evaluated by Folin Ciocalteu's method. One ml of plant extract $(50,150,300,450$ $\mu \mathrm{g} / \mathrm{ml})$, and standard gallic acid $(50,100,150,300,400,450 \mu \mathrm{g} / \mathrm{ml})$ was placed in the test tube, and $5 \mathrm{ml}$ of distilled water and $0.5 \mathrm{ml}$ of Folin Ciocalteu's reagent was mixed and shaken. After $5 \mathrm{~min}, 1.5 \mathrm{ml}$ of $20 \%$ of sodium carbonate $\left(\mathrm{Na}_{2} \mathrm{CO}_{3}\right)$ was added and made up to $10 \mathrm{ml}$ with distilled water. This was incubated for $2 \mathrm{~h}$ at room temperature, and intense blue colour developed. After incubation, absorbance was measured at $750 \mathrm{~nm}$ with a spectrophotometer (Anthos Zenyth $200 \mathrm{UV} / \mathrm{Vis}$ spectrophotometer). The experiment was performed in triplicates. The blank was done using reagent blank with solvent. The calibration curve was plotted using standard gallic acid. The data for total phenolic contents of plant extracts were expressed as mg of gallic acid equivalent weight (GAE)/100 $\mathrm{g}$ of dry weight (Samidha et al., 2014, Aryal et al., 2019).

\subsection{Determination of total flavonoid content}

The total flavonoid content was evaluated with the aluminium chloride colourimetric assay. One $\mathrm{ml}$ of plant extract $(50,150,300,450 \mu \mathrm{g} / \mathrm{ml})$ and $1 \mathrm{ml}$ of standard quercetin solution $(50,100,150,300,400,450 \mu \mathrm{g} / \mathrm{ml})$ was added into test tubes and followed by $4 \mathrm{ml}$ of distilled water, and $0.3 \mathrm{ml}$ of $5 \%$ sodium nitrite solution. After $5 \mathrm{~min}$, $0.3 \mathrm{ml}$ of $10 \%$ aluminium chloride was added. At the $6^{\text {th }}$ min, $2 \mathrm{ml}$ of $1 \mathrm{M}$ sodium hydroxide was added. The final volume was adjusted to $10 \mathrm{ml}$ with distilled water and mixed well. The formation of orange yellowish colour was observed. The absorbance was measured at $510 \mathrm{~nm}$ with Athos Zenyth $200 \mathrm{UV} /$ Vis spectrophotometer. The plant experiment was performed in triplicates. The blank was done using distilled water. Quercetin was used as a standard. The calibration curve was plotted using standard quercetin. The data of total flavonoids of plant extracts were expressed as mg of quercetin equivalents to $100 \mathrm{~g}$ of plant dry mass (Aryal et al., 2019, Chandra et al., 2014).

\subsection{In vitro antioxidant assay - 2, 2-Diphenyl-1-picrylhydrazyl (DPPH) radical scavenging assay}

The DPPH radical-scavenging activity was carried out using the methods previously described by (Alara $e t$ al., 2017). Essentially $0.3 \mathrm{mM}$ of DPPH was prepared fresh in ethanoic solution, and $10 \mathrm{mg}$ of each plant extract in various concentrations $(10,30,40$ and $50 \mathrm{mg} / \mathrm{ml})$ was dissolved in $2 \mathrm{ml}$ of methanol. Thereafter, $0.1 \mathrm{ml}$ of prepared plant extract was added into a test tube containing $1.9 \mathrm{ml}$ of DPPH radical solution. The mixtures were vortexed thoroughly and incubated in room temperature in the dark for $30 \mathrm{~min}$. The absorbance was measured at $515 \mathrm{~nm}$ using Anthos Zenyth 200 UV/Vis spectrophotometer. Methanol was used as a blank. Ascorbic acid (Sigma-Aldrich, Johannesburg, South Africa) was used as a standard drug. The percentage of DPPH inhibition was evaluated using an equation that was previously described by (Omede et al., 2018).

$(\%)$ inhibition $=($ Abs Control - Abs Sample $) X 100$

\section{Abs control}

The extracts with a scavenging activity higher than $80 \%$ were considered active. For extracts that had scavenging activity ranged between $50 \%$ and below $80 \%$ inhibition were considered moderate, and inactive were extract with $<50 \%$ inhibition, and those inactive were rejected.

\subsection{2,2'-azino-bis (3-ethylbenzothiazoline-6-sulfonic acid) (ABTS) radical scavenging activity assay}

The ability of selected plant extracts to scavenge free radical activities was determined by ABTS radical decolourization assay. The assay was previously described by (Re et al., 1999), and it was further modified for this 
study. Briefly, ABTS+ cation radical was produced by the reaction between $7 \mathrm{mM}$ ABTS in water, and $2.45 \mathrm{mM}$ potassium persulfate $(1: 1)$, stored in the dark at room temperature for $12-16 \mathrm{~h}$ before use. ABTS+ solution was then diluted with methanol to obtain an absorbance of 0.700 at $734 \mathrm{mM}$. After the addition of $5 \mu$ plant extract to obtain $3.995 \mathrm{ml}$ of diluted ABTS+ solution, the absorbance was measured at $30 \mathrm{~min}$ after the initial mixing. The methanol solvent blank was run in each assay. The ABTS scavenging capacity of the extract was compared to butylated hydroxytoluene (BHT). The percentage inhibition of absorbance at $734 \mathrm{mM}$ was calculated using the formula here below:

Scavenging capacity $(\%)=\underline{100-[O D \text { sample }- \text { OD sample blank }] \times 100 \%}$

OD control - OD control blank

Where OD represents optical density or absorbance.

\subsection{Alpha-amylase ( $\alpha$-amylase) inhibition assay}

Different concentrations $(50,150,250,350,450 \mu \mathrm{g} / \mathrm{ml})$ of each plant extract $(500 \mu \mathrm{l})$ were incubated with 500 $\mu 1$ of $\alpha$-amylase enzyme solution ( 2 units $/ \mathrm{ml}$ ) was obtained by dissolving $0.001 \mathrm{~g}$ of $\alpha$-amylase in $100 \mathrm{ml}$ of $0.02 \mathrm{M}$ sodium phosphate buffer $\mathrm{pH} 6.9$ with $6.7 \mathrm{mM}$ sodium chloride) at room temperature $\left(32^{\circ} \mathrm{C}\right)$ for approximately $10 \mathrm{~min}$. After incubation period this was followed by the addition of $500 \mu \mathrm{l}$ of $1 \%$ starch solution (dissolving $1 \mathrm{~g}$ of potato starch in $100 \mathrm{ml}$ of distilled water with boing and stirring for $15 \mathrm{~min})$ and incubated at room temperature $\left(32^{\circ} \mathrm{C}\right)$ for further $10 \mathrm{~min}$. After the incubation period, $1 \mathrm{ml}$ of 3,5-dintro salicylic acid (DNSA) reagent was obtained by dissolving $1 \mathrm{~g}$ of DNSA in $50 \mathrm{ml}$ of distilled water and added $30 \mathrm{~g}$ of sodium potassium tartrate is small lots, and the solution turns milky yellow. In the mixture above, $20 \mathrm{ml}$ of $2 \mathrm{~N}$ sodium hydroxide was added and it turns transparent orange-yellow colour and this was made up to a mark of $100 \mathrm{ml}$ in a volumetric flask. The reagent was wrapped with foil and kept in the dark was added to stop the reaction and was incubated in a hot water bath $\left(85^{\circ} \mathrm{C}\right)$ for 5 min. The reaction was observed after 5 min' incubation time where the colour changed to orange-red and was removed from the water bath and cooled to room temperature.

The mixture was further diluted with $5 \mathrm{ml}$ distilled water. The plant extracts in different concentrations were performed in triplicates. Individual blank was performed by replacing an enzyme with a buffer. Controls were performed by replacing plant extracts with solvent. Acarbose ${ }^{\mathrm{TM}}(500 \mu \mathrm{g} / \mathrm{ml})$ was used as positive controls in the following concentrations $(100,200,300,400$ and $500 \mu \mathrm{g} / \mathrm{ml})$. Absorbance was measured at $540 \mathrm{~nm}$ with Anthos Zenyth $200 \mathrm{UV} / \mathrm{Vis}$ spectrophotometer. The percentage inhibition of $\alpha$-amylase was analyzed using the equation here below:

\%inhibition $\left.=\underline{(A}_{540 \text { Control }}-\mathrm{B}_{540 \text { Extract }}\right) \times 100$

A 540 Control

\section{STATISTICAL ANALYSIS}

The experimental results were expressed as mean \pm standard deviation of three parallel measurements. Linear regression analysis was used to calculate the $\mathrm{IC}_{50}$ values. Significance difference $(* * \mathrm{p}<0.05)$ and $(* * * \mathrm{p}<0.0001)$ was determined using student " $\mathrm{t}$ " test by one-way ANOVA, Tukey's multiple comparison test, and Dunnet test in Prism version 5.0.

\section{RESULTS}

The purpose of this study was to evaluate preliminary phytochemicals, total phenolic content, total flavonoid content, antioxidants, and alpha $(\alpha)$-amylase potential on the selected South Africa plant extracts. Thirteen phytochemicals were screened using standardized methods (Table 2). Furthermore, the determination of total phenol content and total flavonoid content were conducted in this study (Fig. 1, Fig. 2, and Table 3). In addition to this, the ability of plant extracts to scavenging free radicals was evaluated using DPPH radical scavenging assay (Fig. 3 and Fig. 4), and ABTS radical scavenging assay (Fig. 5). Finally, the ability of plant extracts to inhibit $\alpha$-amylase (Fig. 6) was also evaluated.

\subsection{Qualitative phytochemicals}

This publication is licensed under Creative Commons Attribution CC BY.

http://dx.doi.org/10.29322/IJSRP.11.10.2021.p11822

WWW.ijsrp.org 
The qualitative phytochemicals investigations are showed the presence of phytochemicals in various concentrations, and the results are summarised in Table 2 here below. 
Table 2: Qualitative analysis of phytochemicals results of nine plant extracts.

\begin{tabular}{|c|c|c|c|c|c|c|c|c|c|c|c|c|c|c|}
\hline Plant extracts & Part & ${ }^{\mathrm{a} A L K}$ & ${ }^{\mathrm{b}} \mathrm{CAR}$ & 'FLA & dPHE & 'SAP & fSTE & gTA & ${ }^{\mathrm{h}} \mathrm{ANT}$ & ${ }^{\mathrm{i} B E C}$ & ${ }^{\mathrm{j}} \mathrm{COU}$ & ${ }^{\mathrm{k}} \mathrm{CRB}$ & ${ }^{\mathrm{m}} \mathrm{QUI}$ & ${ }^{\text {nTEP }}$ \\
\hline Euclea crispa & $\mathrm{L}$ & - & - & + & + & + & - & + & + & - & + & - & + & + \\
\hline Euclea natalensis & $\mathrm{L}$ & - & - & + & + & + & - & + & + & - & + & + & + & + \\
\hline Schkuhria pinnata & $\mathrm{L}$ & + & - & + & + & - & - & - & - & + & + & - & + & + \\
\hline Ziziphus mucronata & $\mathrm{L}$ & + & - & + & + & + & - & + & + & + & + & + & + & + \\
\hline Ziziphus mucronata & $\mathrm{F}$ & + & - & + & + & + & - & + & + & + & + & + & + & + \\
\hline Lippia javanica & $\mathrm{L}$ & + & + & + & + & + & + & + & - & + & + & - & - & + \\
\hline Vernonia oligocephala & $\mathrm{L}$ & + & - & + & + & + & + & + & + & - & + & - & - & + \\
\hline Clerodendrum myricoides & $\mathrm{L}$ & + & + & + & + & + & + & + & + & - & + & - & - & + \\
\hline Erythrina lysistemon & $\mathrm{L}$ & + & + & + & + & - & + & + & + & - & + & - & + & + \\
\hline
\end{tabular}

L: Leaf; F: fruit; ${ }^{\mathrm{a} A L K}$ : Alkaloids; ${ }^{\mathrm{b} C A R: ~ C a r d i a c ~ g l y c o s i d e s ; ~}{ }^{\mathrm{c}} \mathrm{FLA}$ : flavonoids; ${ }^{\mathrm{d}}$ PHE: phenols; ${ }^{\mathrm{e}} \mathrm{SAP}$ : saponins; ${ }^{\mathrm{f}} \mathrm{STE}$ : steroids; ${ }^{\mathrm{g}} \mathrm{TA}$ : tannins; ${ }^{\mathrm{h}} \mathrm{ANT}$ : anthocyanin; ${ }^{\mathrm{i} B E C}$ : Bectacynin; ${ }^{\mathrm{j}} \mathrm{COU}$ : coumarins; ${ }^{\mathrm{k}} \mathrm{CRB}$ : carbohydrates; ${ }^{\mathrm{m} Q U I}$ : quinones; ${ }^{\mathrm{m} T E P}$ : terpenoids; +: present and -: absent. 


\subsection{The determination of total phenolic content}

Gallic acid

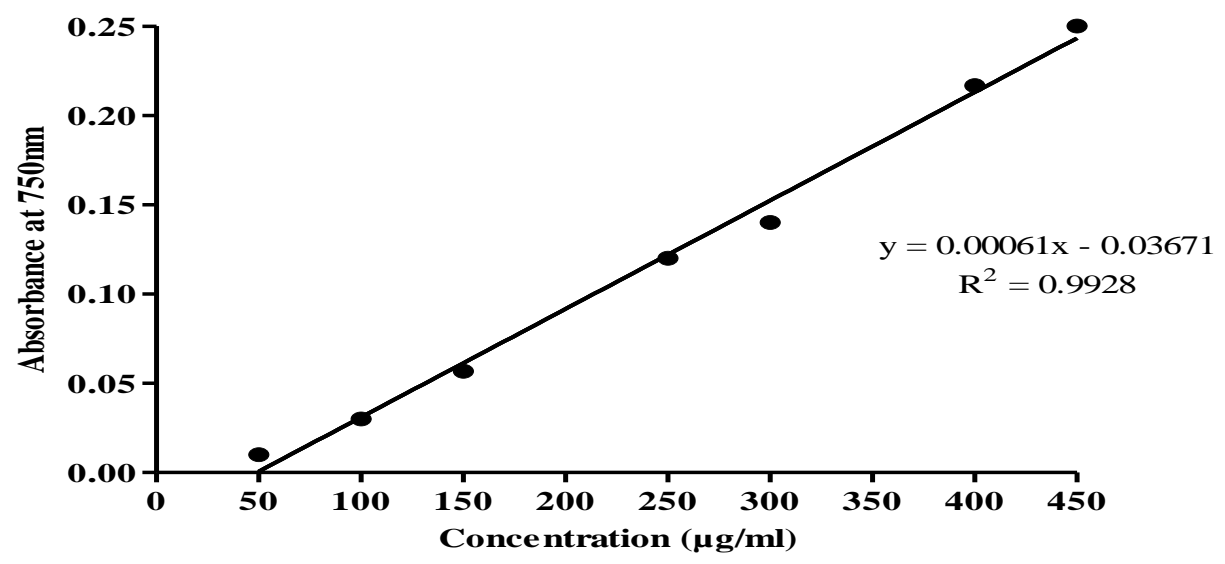

Fig. 1: Total phenolic content for standard gallic acid. $R^{2}$ value represented mean data of $n=3$

\subsection{The determination of total flavonoids}

\section{Quercetin}

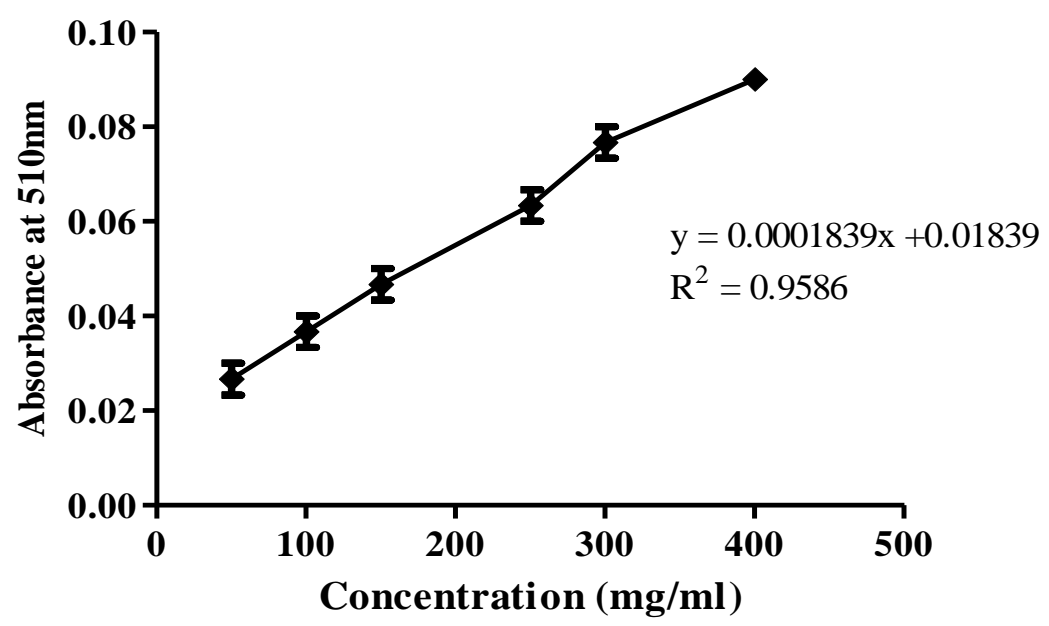

Fig. 2: Total flavonoids content for standard quercetin. R2 value represents the mean data set of $(n=3)$ 
Table 3: Total phenolic content, and total flavonoids content of the selected South African plant extracts.

\begin{tabular}{|l|l|l|l|l|}
\hline \multirow{2}{*}{ Plant species } & Plant parts & $\begin{array}{l}\text { Concentrations } \\
(\boldsymbol{\mu g} / \mathbf{m l})\end{array}$ & $\begin{array}{l}\text { TPC } \\
(\mathbf{m g} \mathbf{G A E} / \mathbf{g}) *\end{array}$ & $\begin{array}{l}\text { (mg of quercetin } \\
\text { equivalent/g } \\
\text { material })\end{array}$ \\
\hline Euclea crispa & Leaf & 50 & $36,60 \pm 0.94$ & $4,60 \pm 0.94$ \\
\hline & & 100 & $46,19 \pm 1.41$ & $10,90 \pm 0.94$ \\
\hline & & 150 & $57,79 \pm 0.94$ & $32,95 \pm 0.94$ \\
\hline & & 250 & $70,39 \pm 1.41$ & $36,43 \pm 1.41$ \\
\hline & & 300 & $71,99 \pm 2.36$ & $38,80 \pm 1.41$ \\
\hline & & 400 & $82,58 \pm 0.94$ & $49,26 \pm 0.94$ \\
\hline & & 450 & $93,18 \pm 1.41$ & $61,05 \pm 2.36$ \\
\hline & Leaf & 50 & $13,51 \pm 0.94$ & $6,18 \pm 0.94$ \\
\hline & & 100 & $36,67 \pm 0.94$ & $12,81 \pm 1.41$ \\
\hline & & 150 & $61,75 \pm 1.41$ & $16,75 \pm 1.41$ \\
\hline & & 250 & $72,26 \pm 0.94$ & $32,50 \pm 1.41$ \\
\hline & & 300 & $82,77 \pm 0.94$ & $48,24 \pm 1.41$ \\
\hline & & 400 & $93,28 \pm 1.41$ & $64,33 \pm 1.89$ \\
\hline & & 450 & $93,80 \pm 1.89$ & $79,74 \pm 1.41$ \\
\hline & Leaf & 50 & $1,93 \pm 0.47$ & $3,70 \pm 1.89$ \\
\hline & & 100 & $7,72 \pm 0.47$ & $18,39 \pm 0.94$ \\
\hline & & 150 & $21,23 \pm 1.41$ & $34,09 \pm 1.41$ \\
\hline & & 250 & $38,60 \pm 0.47$ & $49,11 \pm 0.94$ \\
\hline & & 300 & $44,39 \pm 0.94$ & $64,81 \pm 1.41$ \\
\hline & & 400 & $50,18 \pm 1.89$ & $80,17 \pm 1.41$ \\
\hline & & 450 & $55,96 \pm 1.41$ & $82,34 \pm 1.41$ \\
\hline
\end{tabular}




\begin{tabular}{|c|c|c|c|c|}
\hline Plant species & Plant parts & $\begin{array}{l}\text { Concentrations } \\
(\mu \mathrm{g} / \mathrm{ml})\end{array}$ & $\begin{array}{l}\text { TPC } \\
(\mathbf{m g ~ G A E} / \mathrm{g}) *\end{array}$ & $\begin{array}{l}\text { TFC } \\
\text { (mg of quercetin } \\
\text { equivalent/g dry } \\
\text { material) }\end{array}$ \\
\hline \multirow[t]{7}{*}{ Ziziphus mucronata } & Leaf & 50 & $7,72 \pm 0.47$ & $2,24 \pm 0.94$ \\
\hline & & 100 & $19,30 \pm 1.41$ & $3,70 \pm 1.89$ \\
\hline & & 150 & $30,88 \pm 1.89$ & $4,60 \pm 0.94$ \\
\hline & & 250 & $36,67 \pm 0.94$ & $5.39 \pm 0.94$ \\
\hline & & 300 & $47,25 \pm 0.94$ & $26,45 \pm 1.41$ \\
\hline & & 400 & $57,83 \pm 1.41$ & $47,17 \pm 1.41$ \\
\hline & & 450 & $68,40 \pm 0.94$ & $67,56 \pm 0.94$ \\
\hline \multirow[t]{7}{*}{ Ziziphus mucronata } & Fruits & 50 & $13,51 \pm 1.41$ & $2,58 \pm 1.41$ \\
\hline & & 100 & $25,09 \pm 1.41$ & $3,36 \pm 1.41$ \\
\hline & & 150 & $46,32 \pm 0.94$ & $4,60 \pm 0.94$ \\
\hline & & 250 & $55,97 \pm 1.41$ & $7,75 \pm 0.94$ \\
\hline & & 300 & $66,54 \pm 0.94$ & $34,02 \pm 1.41$ \\
\hline & & 400 & $77,12 \pm 1.41$ & $60,29 \pm 1.89$ \\
\hline & & 450 & $87,70 \pm 1.41$ & $65,56 \pm 0.94$ \\
\hline \multirow[t]{7}{*}{ Lippia javanica } & Leaf & 50 & $1,93 \pm 0.47$ & $3,03 \pm 0.94$ \\
\hline & & 100 & $5,79 \pm 0.94$ & $4,94 \pm 1.41$ \\
\hline & & 150 & $7,72 \pm 0.47$ & $20,87 \pm 1.41$ \\
\hline & & 250 & $21,23 \pm 1.41$ & $36,81 \pm 1.41$ \\
\hline & & 300 & $34,74 \pm 0.94$ & $53,08 \pm 1.89$ \\
\hline & & 400 & $48,25 \pm 0.94$ & $68,69 \pm 1.41$ \\
\hline & & 450 & $61,76 \pm 1.41$ & $74,62 \pm 1.41$ \\
\hline
\end{tabular}




\begin{tabular}{|l|l|l|l|l|}
\hline Plant species & & & & TFC \\
& Plant parts & $\begin{array}{l}\text { Concentrations } \\
(\boldsymbol{\mu g} / \mathbf{m l})\end{array}$ & $\begin{array}{l}\text { TPC } \\
(\mathbf{m g ~ G A E} / \mathbf{g})\end{array}$ & $\begin{array}{l}\text { equivalent/g } \\
\text { material) }\end{array}$ \\
\hline Vernonia oligocephala & & 50 & $1,93 \pm 0.47$ & $2,91 \pm 1.89$ \\
\hline & Leaf & 100 & $3,86 \pm 0.94$ & $23,48 \pm 1.89$ \\
\hline & & 150 & $5,79 \pm 0.47$ & $44,06 \pm 1.89$ \\
\hline & & 250 & $5,72 \pm 0.94$ & $64,30 \pm 1.41$ \\
\hline & & 300 & $23,44 \pm 1.41$ & $74,88 \pm 1.41$ \\
\hline & & 400 & $39,16 \pm 1.41$ & $79,88 \pm 1.41$ \\
\hline & & 450 & $54,88 \pm 0.94$ & $85,45 \pm 1.41$ \\
\hline & Leaf & 50 & $3,86 \pm 0.94$ & $2,58 \pm 1.41$ \\
\hline & & 100 & $7,72 \pm 0.94$ & $3,70 \pm 1.89$ \\
\hline & & 150 & $11,58 \pm 1.41$ & $19,06 \pm 1.89$ \\
\hline & & 250 & $19,30 \pm 1.41$ & $34,09 \pm 1.41$ \\
\hline & & 300 & $35,02 \pm 1.41$ & $49,78 \pm 1.89$ \\
\hline & & 400 & $50,74 \pm 1.89$ & $64,14 \pm 0.47$ \\
\hline & & 450 & $66,46 \pm 0.94$ & $80,51 \pm 1.89$ \\
\hline & Leaf & 50 & $17,37 \pm 0.94$ & $6,51 \pm 1.41$ \\
\hline & & 100 & $42,46 \pm 1.89$ & $7,30 \pm 1.41$ \\
\hline & & 150 & $52,91 \pm 1.89$ & $23,48 \pm 2.36$ \\
\hline & & 250 & $63,37 \pm 1.41$ & $38,66 \pm 1.89$ \\
\hline & & 400 & $73,82 \pm 0.47$ & $54,17 \pm 1.89$ \\
\hline & & 450 & $84,28 \pm 2.83$ & $70,02 \pm 2.36$ \\
\hline & & $94,74 \pm 0.94$ & $75,87 \pm 1.41$ \\
\hline
\end{tabular}

*all values are expressed as mean \pm standard error means $(\mathrm{SEM})(\mathrm{n}=3), \mathrm{TPC}=$ Total phenolic content, and TFC $=$ Total flavonoids content. 


\subsection{In vitro antioxidant assay - 2, 2-Diphenyl-1-picrylhydrazyl (DPPH) radical}

The determination of antioxidant activity from nine plant extracts were evaluated using DPPH radical scavenging activity. The standard curve of ascorbic acid was measured and shown in Fig. 3. The results are expressed in percentage of inhibition; of which active extract was above 50\% and anything below 50\% was considered inactive and rejected. Four active plant extracts are summarised (Fig. 4) here below. One-way ANOVA was used to establish statistical significance between plant extracts and concentrations used. A degree of significance was observed with one or two concentrations used. The inhibition effects that were observed for Schkuhria pinnata showed $95 \%$ inhibition $(50 \mathrm{mg} / \mathrm{ml})$ and Lippia javanica showed $95 \%$ inhibition $(50 \mathrm{mg} / \mathrm{ml})$ Clerodendrum myricoides showed $93 \%$ inhibition $(50 \mathrm{mg} / \mathrm{ml})$, and Erythrina lysistemon showed $92 \%$ inhibition $(50 \mathrm{mg} / \mathrm{ml})$, respectively. The significant difference between groups was observed ** $(\mathrm{P}<0.005)$ between $S$. pinnata vs $C$. myricoides, S. pinnata vs E, lysistemon, and L. javanica vs E. lysistemon. It can be further seen that the inhibition has a dose- respond.

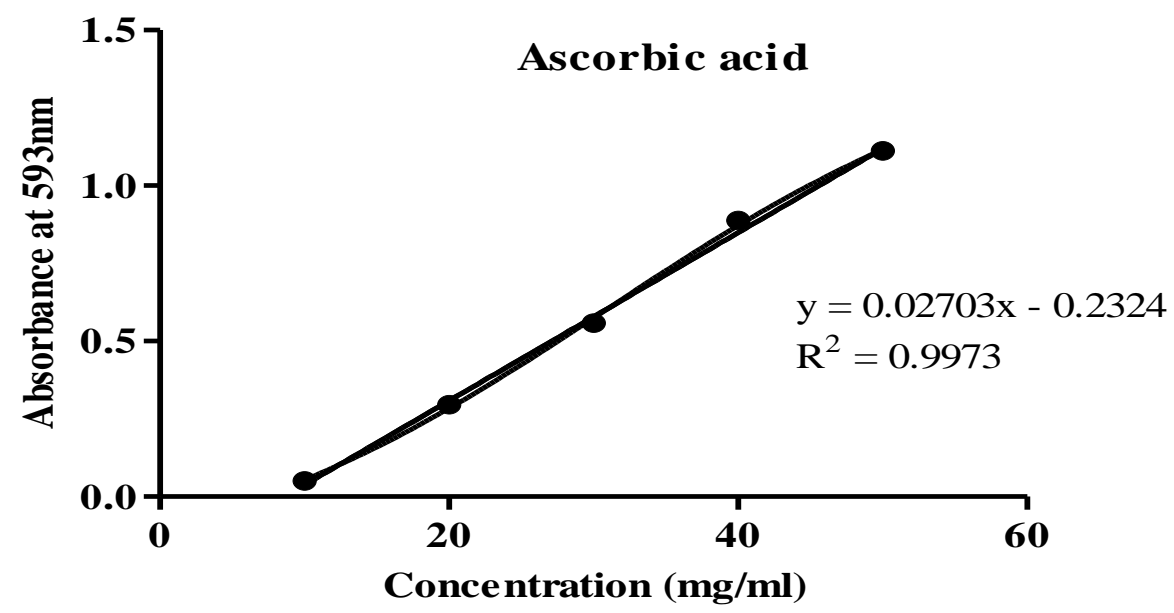

Fig. 3: In vitro antioxidant (DPPH) assay for standard Ascorbic acid. $\mathrm{R}^{2}$ values represented mean data set of $\mathrm{n}=3$

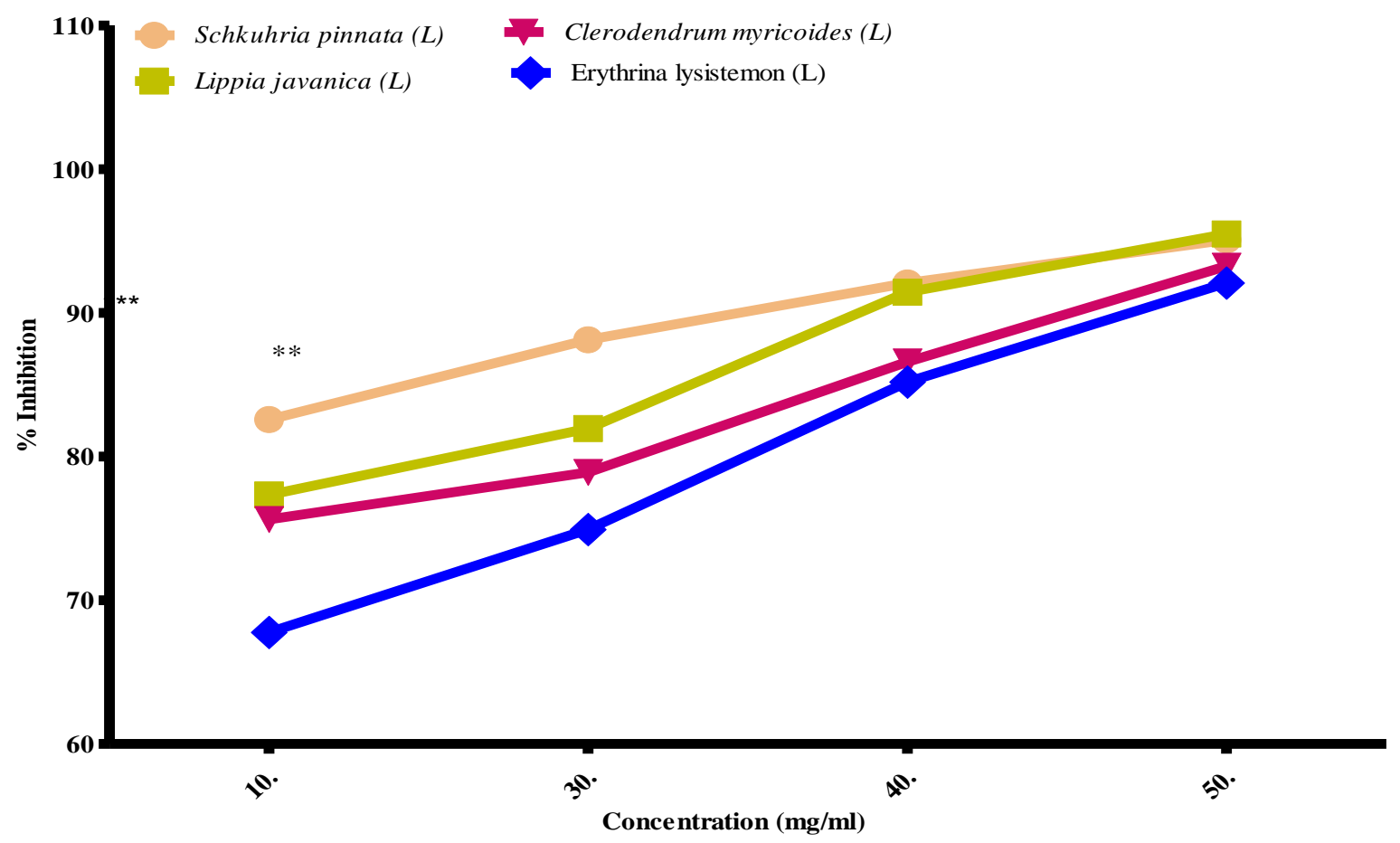

Fig. 4: DPPH scavenging activities for Schkuhria pinnata $\left(\mathrm{IC}_{50}=38.244 \mathrm{mg} / \mathrm{ml}\right)$, Lippia javanica $\left(\mathrm{IC}_{50}=34.966 \mathrm{mg} / \mathrm{ml}\right)$, Erythrina lysistemon $\left(\mathrm{IC}_{50}=37.828 \mathrm{mg} / \mathrm{ml}\right.$ ), and Clerodendrum myricoides $\left(\mathrm{IC}_{50}=38.939 \mathrm{mg} / \mathrm{ml}\right)$. L: Leaf, and F: fruit. (Significant, $* * \mathrm{p}<0.005)$. 


\subsection{ABTS radical scavenging activity assay}

The four plant extracts that demonstrated good scavenging activity against DPPH radical assay were further validated with ABTS and similar results were observed (Fig. 5). The inhibition effects and $\mathrm{IC}_{50}$ value were observed for Clerodendrum myricoides showed $88 \%$ inhibition $(0.04 \mathrm{mg} / \mathrm{ml})$, and $\mathrm{IC}_{50}$ value of $7.148 \mathrm{mg} / \mathrm{ml}$, for Erythrina lysistemon showed $86 \%$ inhibition $(0.04 \mathrm{mg} / \mathrm{ml})$, and IC 50 value of $5.353 \mathrm{mg} / \mathrm{ml}$ Schuhria pinnata showed $85 \%$ inhibition $(0.04 \mathrm{mg} / \mathrm{ml})$, and IC $_{50}$ value of $0.944 \mathrm{mg} / \mathrm{ml}$ and Lippia javanica showed $83 \%$ inhibition $(0.04 \mathrm{mg} / \mathrm{ml})$, and $\mathrm{IC}_{50}$ value of $0.759 \mathrm{mg} / \mathrm{ml}$. The standard inhibitor BHT showed $97 \%(0.04 \mathrm{mg} / \mathrm{ml})$. The significant difference between plant extracts and BHT was observed to be $* *(\mathrm{p}<0.05)$.

\section{Schkuhria pinnata $(L)$ \\ Clerodendrum myricoides $(L)$ \\ Lippia javanica $(L)$

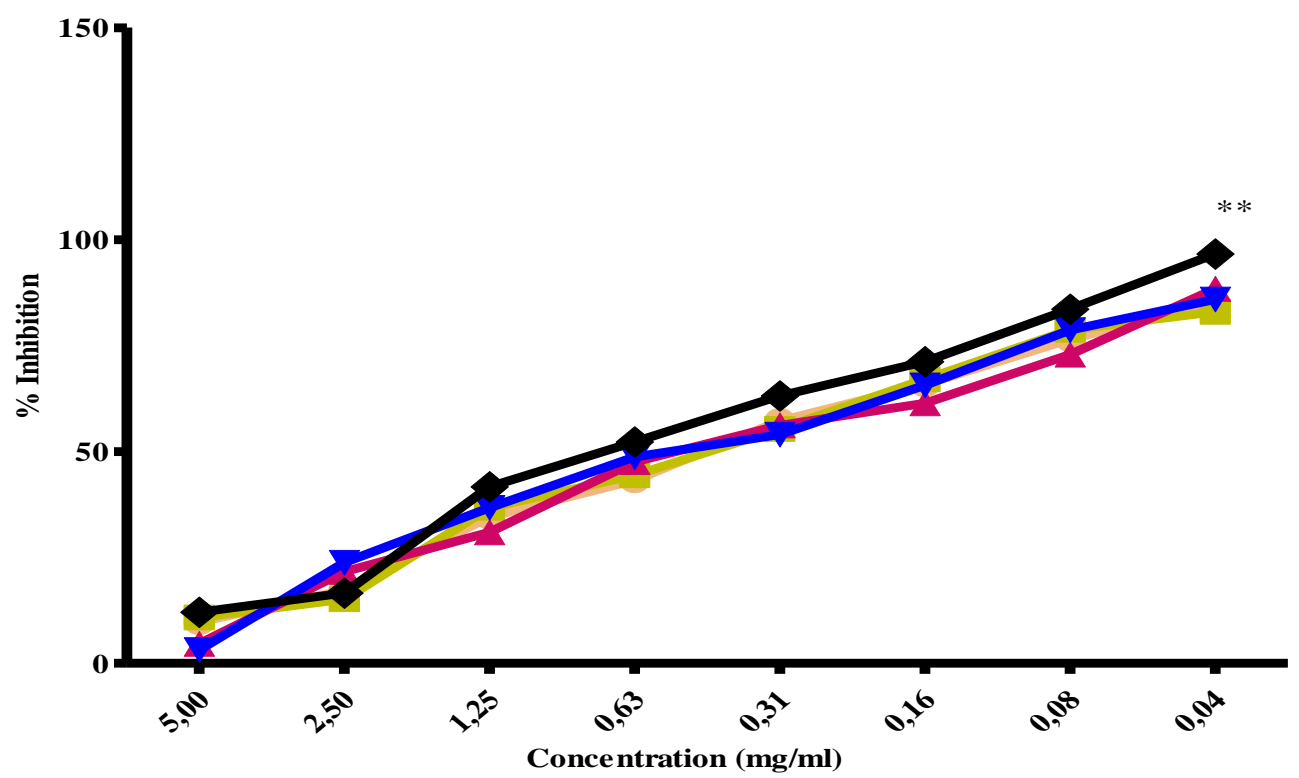

Fig. 5: ABTS scavenging activities for Schkuhria pinnata $\left(\mathrm{IC}_{50}=0.944 \mathrm{mg} / \mathrm{ml}\right)$, Lippia javanica $\left(\mathrm{IC}_{50}=0.759 \mathrm{mg} / \mathrm{ml}\right)$, Erythrina lysistemon (IC ( $_{50}=5.353 \mathrm{mg} / \mathrm{ml}$ ), and Clerodendrum myricoides $\left(\mathrm{IC}_{50}=7.148 \mathrm{mg} / \mathrm{ml}\right)$. L: Leaf, and F: fruit. (Significant between groups and control $\left(\right.$ HBT $\left(\right.$ IC $\left.\left._{50}=\mathbf{2 . 7 6 3 ~ m g / m l}\right)\right), * *(p<0.005)$.

\subsection{In vitro inhibitory $\alpha$-amylase assay}

Nine selected plant extracts were used to assess the ability of $\alpha$-amylase inhibitory effects and were compared with a known inhibitor (Acarbose ${ }^{\mathrm{TM}}$ ). A degree of $\alpha$-amylase was observed in all plant extracts which ranged from $9 \%$ to $98 \%$. However, only four plant extracts demonstrated a good inhibition effect, and similar results were observed for Acarbose ${ }^{\mathrm{TM}}$. Essentially, plant extracts were further quantified by chromogenic DNSA method and good inhibition effects was observed and lower $\mathrm{IC}_{50}$ values for Schkuhria pinnata $\left(\mathrm{IC}_{50}=52.673 \mu \mathrm{g} / \mathrm{ml}\right)$, and Clerodendrum myricoides $\left(\mathrm{IC}_{50}=322.287 \mu \mathrm{g} / \mathrm{ml}\right)$ showed $98 \%$ inhibition $(450 \mu \mathrm{g} / \mathrm{ml})$, Erythrina lysistemon $\left(\mathrm{IC}_{50}=205.089 \mu \mathrm{g} / \mathrm{ml}\right)$ showed $97 \%$ inhibition $(450 \mu \mathrm{g} / \mathrm{ml})$, and Lippia javanica $\left(\mathrm{IC}_{50}=247.708 \mu \mathrm{g} / \mathrm{ml}\right)$ showed $96 \%$ inhibition $(450$ $\mu \mathrm{g} / \mathrm{ml})$. The standard inhibitor Acarbose ${ }^{\mathrm{TM}}\left(\mathrm{IC}_{50}=291.395 \mu \mathrm{g} / \mathrm{ml}\right)$ showed $87 \%(450 \mu \mathrm{g} / \mathrm{ml})$. The significant difference was observed between groups $* *(\mathrm{p}<0.05)$ and between groups and control $* * *(\mathrm{p}<0.0001)$. 


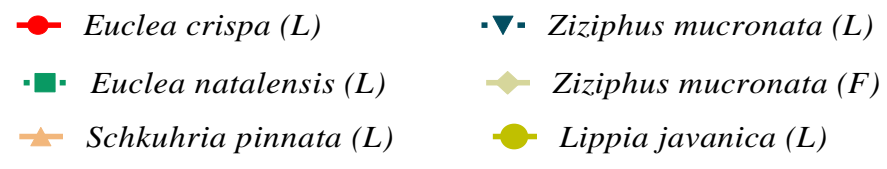

Vernonia oligocephala $(L)$

Clerodendrum myricoides $(L$

Erythrina lysistemon $(L)$ Acarbose

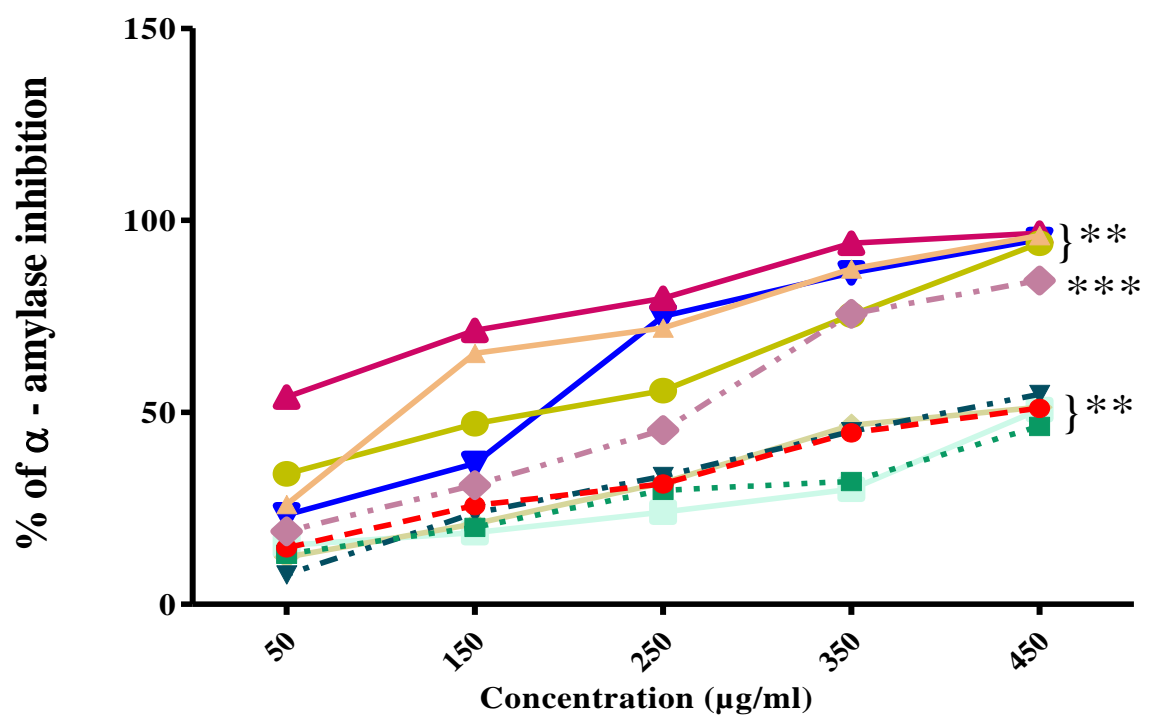

Fig. 6: $\alpha$-amylase inhibition activity of Acarbose ${ }^{\mathrm{TM}}$ and nine selected plant extracts. L: Leaf, and F: fruit. The four plant extract exhibited good $\alpha$-amylase inhibition and lower $\mathrm{IC}_{50}$ values were measured for Schkuhria pinnata $\left(\mathrm{IC}_{50}=52.673 \mu \mathrm{g} / \mathrm{ml}\right)$, and Clerodendrum myricoides $\left(\mathrm{IC}_{50}=322.287 \mu \mathrm{g} / \mathrm{ml}\right)$ showed $98 \%$ inhibition $(450 \mu \mathrm{g} / \mathrm{ml})$, Erythrina lysistemon $\left(\mathrm{IC}_{50}=205.089 \mu \mathrm{g} / \mathrm{ml}\right)$ showed $97 \%$ inhibition $(450 \mu \mathrm{g} / \mathrm{ml})$, and Lippia javanica $\left(\mathrm{IC}_{50}=247.708 \mu \mathrm{g} / \mathrm{ml}\right)$ showed $96 \%$ inhibition $(450 \mu \mathrm{g} / \mathrm{ml})$. The standard inhibitor Acarbose ${ }^{\mathrm{TM}}\left(\mathrm{IC}_{50}=291.395 \mu \mathrm{g} / \mathrm{ml}\right)$ showed $87 \%(450 \mu \mathrm{g} / \mathrm{ml})$. The (Significant between groups was observed to

\section{2. discussion} be**p<0.05, and for control vs groups to be $* * * \mathrm{p}<0.0001)$.

This study aimed to evaluate preliminary phytochemicals, total phenolic content, total flavonoid content, antioxidants, and alpha $(\alpha)$-amylase potential on the selected South Africa plant extracts. In qualitative analysis, the phytochemicals that were analysed ranged from 7 to 10 out of 13 tested phytochemicals identified. The total phenolic content was determined and results are shown (Fig. 1, and Table 3). For total flavonoid content results are shown (Fig. 2, and Table 3). Four plant extracts demonstrated scavenging activities above $80 \%$, which are Schkuhria pinnata, Lippia javanica, Clerodendrum myricoides, and Erythrina lysistemon (Fig. 4, and Fig. 5). Similarly, these plant extracts also exhibited $\alpha$-amylase inhibition effects of up to $98 \%$ (Fig. 6).

\subsection{Qualitative phytochemicals}

The qualitative phytochemicals investigations conducted on selected plant extracts showed the presence of various phytochemicals constitutes. All plant extracts indicated the presence of flavonoids, phenolics, coumarins, and terpenoids. Alkaloids were not present in Euclea crispa, and Euclea natalensis. Cardio glycosides were present in Lippia javanica, Clerodendrum myricoides, and Erythrina lysistemon. Saponins were present in Euclea crispa, Euclea natalensis, Vernonia oligocephala, Lippia javanica, and Clerodendrum myricoides. Steroids were present in Lippia javanica, Veronia oligocephala, Clerodenrum myricoides, and Erythrina lysistemon. Tannins were present in all plant extracts, except Schkuhria pinnata. Bectaynin was present in Schuhria pinnnata, Ziziphus mucronata (leaf and fruits), and Lippia javanica. Anthocynin were absent in Schkuhria pinnnata, and Lippia javanica. Carbohydrates were present in Euclea natalensis and Ziziphus mucronata (leaf and fruits). Quinones was not present in Lippa javanica, Vernonia oligocephala and Clerodendrum myricoides. The phytochemicals that have been identified in this study have been extensively studied and their uses in literature.

Flavonoids are naturally found in fruits, vegetables, grains, bark, roots, stems, flowers, tea, and wine (Panche et al., 2016, Ali, 2011). Interestingly, flavonoids play an important role in the following industries such as nutraceutical, pharmaceutical, medicinal and cosmetic applications (Panche et al., 2016). In recent research has shown that flavonoids contribute towards anti-inflammatory, antimutagenic and anti-carcinogenic properties coupled with their capacity to modulate key cellular enzyme function (Kumar and Pandey, 2013, Ayaz et al., 2019). 
The phenolics are organic compounds and are found in various plant species, and have protective effects against infection and herbivory by an insect (Ali, 2011). The protective effects attribute to anti-inflammatory and antiseptic and can have anti-viral properties (Cianciosi et al., 2018, Shahidi and Yeo, 2018). Coumarins an aromatic organic chemical compound that is colourless crystalline solid with a sweet odour resembling the scent of vanilla and a bitter taste (Jain and Joshi, 2012). They are naturally found in various plant species and can serve as a defence against predators (Yamane et al., 2010). Coumarins have been reported to possess the biological activity and have limited approval for a few medical uses as pharmaceuticals, such as in the treatment of lymphedema (Musa et al., 2008). The terpenoids are natural chemical compounds that are present in all living organisms (Pichersky and Raguso, 2018). Terpenoids are found in abundance mostly in green plants and, particularly, flowering plants, when compared with living organisms (Bergman et al., 2019). Essentially, terpenoids have a variety of functions such as hormones, components of electron transfer systems, protein modification agents, membrane fluidity determinants, and antioxidants (Tan et al., 2018, Bergman et al., 2019).

Alkaloids are naturally occurring in plants, and more common in certain families of flowering plants (Hussain et al., 2018). The most common alkaloids are morphine, codeine, erogonive, and ephedrine (Sayhan et al., 2017, Harborne, 1993). They provide protective effects on plants against predators such as insects (War et al., 2012, Furstenberg-Hagg et al., 2013). Furthermore, alkaloids have diverse medicinal properties such as relief of pain (morphine) (Shoaib et al., 2016, Hussain et al., 2018), treat analgesic (codeine) (Bhandari et al., 2011), treatment of arrhythmias (quinidine) (Eyal, 2018), and useful for blood-vessel constrictors (ergonovine and ephedrine) (Hartmann, 2004). In addition to this, ergonovine is used to reduce uterine haemorrhage after birth (Weeks, 2015, Chelmow, 2008), and finally, ephedrine has been used often for the relief of discomfort associated with common colds, sinusitis, hay fever, and bronchial asthma (Thacher, 1946). Cardiac glycosides are a class of organic compounds that are found in various medical plants (Musa et al., 2008). The compounds that have been isolated from cardio glycosides such as digitoxin, digoxin, and convallotoxin have been reported to support heart strength and rates of contraction (Grosso et al., 2017, Ambrosy et al., 2014). Moreover, cardio glycosides have an additional function which is a diuretic effect that stimulates urine production and aids in the removal of fluid from tissues and the circulatory system (Mladenka et al., 2018). Essentially, cardio glycosides are also used treatments for congestive heart failure, and cardiac arrhythmias (Mashour et al., 1998).

Saponins are a class of chemical compounds that are widely found in varies plant species (Faizal and Geelen, 2013). Researchers have investigated numerous properties of including beneficial and detrimental effects on human health, pesticidal, insecticidal, molluscicidal and fungicidal activity, bitterness and sweetness and other industrial applications such as foaming and surface-active agents (Wagner, 2000, Kharkwal et al., 2012, Wisetkomolmat et al., 2019, Bossou et al., 2013). The steroids are biologically active organic compounds, which are found in various plants, animals and fungi (Dembitsky et al., 2017). The biological function of steroids is to alter membrane fluidity, and also molecule signalling (Dufourc, 2008). Steroids are hormones that play an important role in the alterations in anatomy and physiology during important developmental (Zubeldia-Brenner et al., 2016).

Tannins are polyphenolics which are produced by plants and are bitter (El Gharras, 2009). The bitterness in tannins serves as a protective mechanism against predators such as insects and grazing animals (War et al., 2012). In addition to this, tannins are also useful in curing leather because they tend to contract and astringe tissues by binding with precipitating proteins (Ashok and Upadhyaya, 2012). Anthocyanins are water-soluble and they can either have a red, blue or black pigment which is found in plants and vegetables (Archetti et al., 2009). Anthocyanin is usually found on the blueberry, raspberry, black rice, and black soybean (Khoo et al., 2017). The importance of plants with pigmentations is mainly for signalling, as in attracting pollinating and dispersal agents and repelling herbivores (Lee, 2005). Anthocyanins are used in the food industry as an additive and possess anti-oxidant properties (Khoo et al., 2017). Similarly, bectacyanin are yellow indole-derived pigments found in plants (Khoo et al., 2017). They are commonly noticeable in the petals of flowers but may colour the fruits, leaves, stems, and roots of plants that contain them (Khoo et al., 2017, Miguel, 2018) Essentially they are used as additive as a food dye and they have been observed to possess antioxidants (Miguel, 2018).

Carbohydrates are commonly found in organisms and plants (Ainsworth and Bush, 2011). They are among the first organic compounds formed during photosynthesis (Ainsworth and Bush, 2011). The key function of carbohydrates is a source of energy by all cells (Jéquier, 1994). Also, carbohydrates can be used for the production of cellulose in cell walls, for the synthesis of storage products such as starch (Stein and Granot, 2019). The quinones are secondary metabolites that are found in various plant species (Lu et al., 2013). Quinones possess biological activities, such as the purgative effect of as well as the antibacterial and anti-cancer activities (Koyama et al., 2010, Bolton et al., 2000). Moreover, quinine has been instrumental in the derivatives of various natural and artificial colouring substances (dyes and pigments) (Yusuf et al., 2017).

\subsection{The determination of total phenolic content}

The total phenolic content was estimated by Folin Ciaocalteu's method using gallic acid as standard. The reagent was formed after mixing phosphotungstic acid, and phosphomolybdic acid which after oxidation of the phenolic is reduced to a mixture of blue oxides of tungsten and molybdenum. The blue colouration produced has maximum absorption in the region of $750 \mathrm{~nm}$ and proportional to the total quantity of phenolic compounds originally present. The gallic acid solution of concentration $(50-450 \mu \mathrm{g} / \mathrm{ml})$ conformed to Beer's Law at $750 \mathrm{~nm}$ with a regression coefficient $\left(\mathrm{R}^{2}\right)=0.9928$. the plot has a slope $(\mathrm{m})=0.00061$ and intercept $=0.03671$. The equation of standard curve is $y=0.00061 x+0.03671$ (Fig. 1). In this study it was observed that plant extracts exhibited total phenolic 
content, however, Erythrina lysistemon $(94.71 \pm 0.94 \mathrm{GAE} / \mathrm{g})$, Euclea crispa $(93.18 \pm 1.41 \mathrm{GAE} / \mathrm{g})$, Euclea natalensis $(93.18 \pm 1.89$ GAE/g), Ziziphus mucronata $(87.7 \pm 87.7 \mathrm{GAE} / \mathrm{g})$ exhibited high total phenolic in high concentration $(450 \mu \mathrm{g} / \mathrm{ml})$.

\subsection{The determination of total flavonoid content}

The total flavonoid content was estimated using aluminium chloride colourimetric assay using quercetin as standard. Aluminium chloride forms acid-stable complexes with the C-4 keto groups and either the C-3 or C-5 hydroxide group of flavones and flavonols. Besides, it also forms liable forms complexes with ortho dihydroxide groups in A/B rings of flavonoids. The quercetin solution of concentration $(100-500 \mathrm{mg} / \mathrm{ml})$ conformed to Beer's Law at $510 \mathrm{~nm}$ with a regression coefficient $\left(\mathrm{R}^{2}\right)=0.9586$. The plot has a slope $(\mathrm{m})=0.0001839$ and intercept $=0.01839$. The equation of standard curve is $\mathrm{y}=0.0001839 \mathrm{x}+0.01839($ Fig 2$)$. The total flavonoid content was also observed to have relatively high results. Interestingly, no similar plant extracts exhibited similar results as total phenolic content, however, the following plants exhibited high total flavonoid content in higher concentrations $(450 \mu \mathrm{g} / \mathrm{ml})$. The plant extracts are Vernonia oligocephala $(85.45 \pm 1.41 \mathrm{mgG} / \mathrm{g})$, Schkuhria pinnata $(82.34 \pm 1.41 \mathrm{mgG} / \mathrm{g})$, and Clerodendrum myricoides $(80.51 \pm 1.89$ $\mathrm{mgG} / \mathrm{g})$.

\subsection{In vitro antioxidant assay - 2, 2-Diphenyl-1-picrylhydrazyl (DPPH) radical}

The antioxidant activity was determined using DPPH radical scavenging assay and ascorbic acid was used as standard. The ascorbic acid solution of concentration $(10-50 \mathrm{mg} / \mathrm{ml})$ conformed to Beer's Law at $593 \mathrm{~nm}$ with the regression coefficient $\left(\mathrm{R}^{2}\right)=$ 0.9973. The plot has a slope $(\mathrm{m})=0.02703$ and intercept $=0.2324$. The equation of standard curve is $\mathrm{y}=0.02703 \mathrm{x}-0.2324($ Fig. 3) The results were expressed as a percentage of inhibition and $\mathrm{IC}_{50}$ (where $50 \%$ concentration of the extract scavenged free radical). The lower the $\mathrm{IC}_{50}(\mu \mathrm{g} / \mathrm{ml})$ value the higher the percentage of free radicals. The plant extracts with a scavenging activity higher than $80 \%$ were considered active. For extracts that had scavenging activity ranged between $50 \%$ and below $80 \%$ inhibition were considered moderate and inactive were extract with $<50 \%$ inhibition, and those inactive were rejected. The antioxidant using DPPH radical scavenging activity revealed that four plant extracts scavenged free radicals namely: - Schuhria pinnata $\left(\mathrm{IC}_{50}=38.244 \mathrm{mg} / \mathrm{ml}\right)$, Lippia javanica $\left(\mathrm{IC}_{50}=34.966 \mathrm{mg} / \mathrm{ml}\right)$, and Erythrina lysistemon $\left(\mathrm{IC}_{50}=37.828 \mathrm{mg} / \mathrm{ml}\right)($ Fig. 4).

\subsection{ABTS radical scavenging activity assay}

The plant extracts that were considered active from DPPH were further verified with ABTS antioxidant assay. The results were expressed as percentage inhibition and $\mathrm{IC}_{50}$ (where $50 \%$ concentration of the plant extract scavenged free radical). Essentially, the lower $\mathrm{IC}_{50}(\mathrm{mg} / \mathrm{ml})$ value the higher the percentage inhibition of free radicals. The antioxidant determined using ABTS radical scavenging activity reveals that Schkuhria pinnata $\left(\mathrm{IC}_{50}=0.944 \mathrm{mg} / \mathrm{ml}\right)$, Lippia javanica $\left(\mathrm{IC}_{50}=0.759 \mathrm{mg} / \mathrm{ml}\right)$, Erythrina lysistemon $(\mathrm{IC} 50=5.353$ $\mathrm{mg} / \mathrm{ml})$, Clerodendrum myricoides $\left(\mathrm{IC}_{50}=7.148 \mathrm{mg} / \mathrm{ml}\right),\left(\mathrm{HBT}\left(\mathrm{IC}_{50}=2.763 \mathrm{mg} / \mathrm{ml}\right)(\right.$ Fig. 5). The natural bioactive compounds such as antioxidants normal occur in medicinal plants and they play a pivotal role in scavenging free radicals (Babajide et al., 2010, Kalaivani and Mathew, 2010). In this present study, four plant species exhibited high antioxidant activities in both DPPH and ABTS radical assays. These plant species can play a pivotal role in the prevention of various degeneration diseases, and these results confirm their use in traditional medicine practice purposes (Rice-evans et al., 1995, Xu et al., 2017).

\subsection{In vitro inhibitory $\alpha$-amylase assay}

The plant extracts understudy demonstrated some degree of $\alpha$-amylase inhibition, however, a good inhibition was noticeable Schkuhria pinnata $\left(\mathrm{IC}_{50}=52.673 \mu \mathrm{g} / \mathrm{ml}\right)$, and Clerodendrum myricoides $\left(\mathrm{IC}_{50}=322.287 \mu \mathrm{g} / \mathrm{ml}\right)$ showed $98 \%$ inhibition $(450 \mu \mathrm{g} / \mathrm{ml})$, Erythrina lysistemon $\left(\mathrm{IC}_{50}=205.089 \mu \mathrm{g} / \mathrm{ml}\right)$ showed $97 \%$ inhibition $(450 \mu \mathrm{g} / \mathrm{ml})$, and Lippia javanica $\left(\mathrm{IC}_{50}=247.708 \mu \mathrm{g} / \mathrm{ml}\right) \mathrm{showed}$ 96\% inhibition $(450 \mu \mathrm{g} / \mathrm{ml})$. The standard inhibitor Acarbose ${ }^{\mathrm{TM}}\left(\mathrm{IC}_{50}=291.395 \mu \mathrm{g} / \mathrm{ml}\right)$ showed $87 \%$ inhibition $(450 \mu \mathrm{g} / \mathrm{ml})($ Fig. 6).

The oxidative damage to cells caused by free radicals, especially the damage to DNA, may play a role in the development of cancer, neurodegenerative disorders, cardiovascular diseases, diabetes, and other chronic health conditions (Halliwell, 1994, Diplock et al., 1998, Valko et al., 2007, Oyedemi et al., 2017) plays a significant role in the pathogenesis of metabolic syndrome including diabetes mellitus (DM). The ability of medicinal plants to inhibit $\alpha$-amylase is an important therapeutic target in the regulation of postprandial increase of blood glucose in diabetic patients (Oyedemi et al., 2017). Importantly, the plant species that exhibited good $\alpha$-amylase inhibition activity can be a candidate for use in the blood glucose regulation in diabetic patients.

\section{CONCLUSION}

This study has shown the presence of medicinally important properties in plant species studied. The presence of phytochemicals in plant species shown the usefulness of these plant species in traditional medicine practices. Also, certain plant species in this study demonstrated antioxidant potential and $\alpha$-amylase inhibition potential was observed. The study suggests that the presence of phenolic, flavonoids, antioxidants, and $\alpha$-amylase properties are potential solutions towards the management of diabetes and other chronic inflammatory diseases. The results obtained in this study support the use of these plants in the management of various ailments in traditional medicine practices. 


\section{CONFLICT OF INTEREST}

The authors declare that they do not have any conflict concerning the publication of this paper.

\section{ACKNOWLEDGEMENT}

We thank the College Health Sciences Scholarship Grant at the University of KwaZulu-Natal, Institute of Traditional Knowledge and Traditional Medicine at the Vaal University of Technology, the National Research Foundation and Thuthuka grant for the financial support received towards this study. Dr Ashwell Ndlala is thanks for allowing us to use his chemistry laboratory at Agriculture Research Council, Roodeplaant, Vegetable, and Ornamental Plant Institute. Finally, Ms Nobuhle Mbhele from the Agriculture Research Council, Roodeplaant, Vegetable, and Ornamental Plant Institute is thanked for providing technical assistance towards this work.

\section{REFERENCES}

[1] AINSWORTH, E. A. \& BUSH, D. R. 2011. Carbohydrate export from the leaf: a highly regulated process and target to enhance photosynthesis and productivity. Plant Physiol, 155, 64-9.

[2] ALARA, O. R., ABDURAHMAN, N. H., MUDALIP, S. K. A. \& OLALERE, O. A. 2017. Effect of drying methods on the free radicals scavenging activity of Vernonia amygdalina growing in Malaysia. Journal of King Saud University - Science, 1-5.

[3] ALI, G. 2011. Flavonoids and phenolic acids: Role and biochemical activity in plants and human. Journal of Medicinal Plants Research, 5.

[4] AMBrosy, A. P., BUTLER, J., AHMED, A., VADUGANATHAN, M., VAN VELDHUISEN, D. J., COLUCCI, W. S. \& GHEORGHIADE, M. 2014. The use of digoxin in patients with worsening chronic heart failure: reconsidering an old drug to reduce hospital admissions. J Am Coll Cardiol, 63, $1823-32$.

[5] ARChETTI, M., DORING, T. F., HAGEN, S. B., HUGHES, N. M., LEATHER, S. R., LEE, D. W., LEV-YADUN, S., MANETAS, Y., OUGHAM, H. J., SCHABERG, P. G. \& THOMAS, H. 2009. Unravelling the evolution of autumn colours: an interdisciplinary approach. Trends Ecol Evol, $24,166-73$.

[6] ARYAL, S., BANIYA, M. K., DANEKHU, K., KUNWAR, P., GURUNG, R. \& KOIRALA, N. 2019. Total Phenolic Content, Flavonoid Content and Antioxidant Potential of Wild Vegetables from Western Nepal. Plants 9, 1-12.

[7] ASHOK, P. K. \& UPADHYAYA, K. 2012. Tannins are Astringent. Journal of Pharmacognosy and Phytochemistry, 1, 45-50.

[8] ASLAN, C. E., ZAVALETA, E. S., TERSHY, B. \& CROLL, D. 2013. Mutualism Disruption Threatens Global Plant Biodiversity: A Systematic Review. PLOS ONE, 8, e66993.

[9] AYAZ, M., SADIQ, A., JUNAID, M., ULLAH, F., OVAIS, M., ULLAH, I., AHMED, J. \& SHAHID, M. 2019. Flavonoids as Prospective Neuroprotectants and Their Therapeutic Propensity in Aging Associated Neurological Disorders. Frontiers in Aging Neuroscience, 11.

[10] BABAJIDE, O. J., MABUSELA, W. T., GREEN, I. R., AMEER, F., WEITZ, F. \& IWUOHA, E. I. 2010. Phytochemical screening and biological activity studies of five South African indigenous medicinal plants. Journal of Medicinal Plant Research, 2, 1924-1932.

[11] BAHIENSE, B. J., MARQUES, F. M., FIGUEIRA, M. M., VARGAS, T. S., KONDRATYUK, T. P., ENDRINGER, D. C., SCHERER, R. \& FRONZA, M. 2017. Potential anti-inflammatory, antioxidant and antimicrobial activities of Sambucus australis. Pharmaceutical biology 55, 991-997.

[12] BERGMAN, M. E., DAVIS, B. \& PHILLIPS, M. A. 2019. Medically Useful Plant Terpenoids: Biosynthesis, Occurrence, and Mechanism of Action. Molecules, 24.

[13] BHANDARI, M., BHANDARI, A. \& BHANDARI, A. 2011. Recent updates on codeine. Pharmaceutical Methods, 2, 3-8.

[14] BOADU, A. A. \& ASASE, A. 2017. Documentation of Herbal Medicines Used for the Treatment and Management of Human Diseases by Some Communities in Southern Ghana. Evidence-Based Complementary and Alternative Medicine, 1-12.

[15] BOLTON, J. L., TRUSH, M. A., PENNING, T. M., DRYHURST, G. \& MONKS, T. J. 2000. Role of quinones in toxicology. Chem. Res. Toxicol., 13 , 135.

[16] BOSSOU, A. D., MANGELINCKX, S., YEDOMONHAN, H., BOKO, P. M., AKOGBETO, M. C., DE KIMPE, N., AVLESSI, F. \& SOHOUNHLOUE, D. C. K. 2013. Chemical composition and insecticidal activity of plant essential oils from Benin against Anopheles gambiae (Giles). Parasites \& Vectors, 6, $337-337$.

[17] CHANDRA, S., KHAN, S., AVULA, B., LATA, H., YANG, M. H., ELSOHLY, M. A. \& KHAN, I. A. 2014. Assessment of Total Phenolic and Flavonoid Content, Antioxidant Properties, and Yield of Aeroponically and Conventionally Grown Leafy Vegetables and Fruit Crops: A Comparative Study. Evidence-Based Complementary and Alternative Medicine, 1-9.

[18] CHELMOW, D. 2008. Postpartum haemorrhage: prevention. BMJ clinical evidence, 2008, 1410.

[19] CIANCIOSI, D., FORBES-HERNÁNDEZ, T. Y., AFRIN, S., GASPARRINI, M., REBOREDO-RODRIGUEZ, P., MANNA, P. P., ZHANG, J., BRAVO LAMAS, L., MARTÍNEZ FLÓREZ, S., AGUDO TOYOS, P., QUILES, J. L., GIAMPIERI, F. \& BATTINO, M. 2018. Phenolic Compounds in Honey and Their Associated Health Benefits: A Review. Molecules (Basel, Switzerland), 23, 2322.

[20] DEMBITSKY, V. M., GLORIOZOVA, T. A. \& POROIKOV, V. V. 2017. Biological Activities of Organometalloid (As, At, B, Ge, Si, Se, Te) Steroids. Journal of Applied Pharmaceutical Science, 7 184-202.

[21] DIPLOCK, A. T., CHARLEUX, J. L., GROZIER-WILLI, G., KOK, J., RICE-EVANS, C., ROBERFOID, M., STAHL, W. \& VINA-RIBES, J. 1998. Functional Food Science and Defence Against Reactive Oxidative Species. Journal of Nutrition, 80, S77-S112.

[22] DLUYA, T., DANIEL, D. \& YUSUF, U. 2017. In vitro Antioxidant Activity and Phytochemical Evaluation of Five Medicinal Plants Extract. The Pharmaceutical and Chemical Journal, 4, 73-82.

[23] DUFOURC, E. J. 2008. Sterols and membrane dynamics. Journal of chemical biology, 1, 63-77.

[24] EL GHARRAS, H. 2009. Polyphenols: food sources, properties and applications - a review. International Journal of Food Science \& Technology, $44,2512-2518$.

[25] EYAL, S. 2018. The Fever-Tree: from Malaria to Neurological Diseases. Toxins, 10.

[26] FAIZAL, A. \& GEELEN, D. 2013. Saponins and their role in biological processes in plants. Phytochemistry Reviews, 12, 877-893.

[27] FURSTENBERG-HAGG, J., ZAGROBELNY, M. \& BAK, S. 2013. Plant defence against insect herbivores. Int J Mol Sci, 14, $10242-97$.

[28] GROSSO, F., STOILOV, P., LINGWOOD, C., BROWN, M. \& COCHRANE, A. 2017. Suppression of Adenovirus Replication by Cardiotonic Steroids. Journal of virology, 91, e01623-16.

[29] HALLIWELL, B. 1994. Free radicals, antioxidants, and human disease: curiosity, cause or consequence. Lancet 344, 721-724. 
[30] HARBORNE, J. B., BAXTER, H. \& MOSS, G. P. 1999. Phytochemical Dictionary. A Handbook of Bioactive Compounds from Plants, London, Taylor \& Francis.

[31] HARBORNE, J. B., BAXTER, H. 1993. Pyrrolizidine Alkaloids, Bristol, Phytochemical Dictionary.

[32] HARTMANN, T. 2004. Plant-derived secondary metabolites as defensive chemicals in herbivorous insects: a case study in chemical ecology. Planta, $219,1-4$.

[33] HUANG, S.-S., SU, S.-Y., CHANG, J.-S., LIN, H.-J., WU, W.-T., DENG, J.-S. \& HUANG, G.-J. 2016. Antioxidants, anti-inflammatory, and antidiabetic effects of the aqueous extracts from Glycine species and its bioactive compounds. Botanical studies, 57, 38-38.

[34] HUSSAIN, G., RASUL, A., ANWAR, H., AZIZ, N., RAZZAQ, A., WEI, W., ALI, M., LI, J. \& LI, X. 2018. Role of Plant-Derived Alkaloids and Their Mechanism in Neurodegenerative Disorders. International journal of biological sciences, 14, 341-357.

[35] JAIN , P. K. \& JOSHI, H. 2012. Coumarin: Chemical and Pharmacological Profile. Journal of Applied Pharmaceutical Science 02, $236-240$.

[36] JÉQUIER, E. 1994. Carbohydrates as a source of energy. The American Journal of Clinical Nutrition, 59, 682S-685S.

[37] KADA, S., BOURICHE, H., SENATOR, A., DEMIRTAŞ, I., ÖZEN, T., TOPTANCI, B. C., KıZıL, G. \& KıZIL, M. 2017. Protective activity of Hertia cheirifolia extracts against DNA damage, lipid peroxidation and protein oxidation. Pharmaceutical biology, 55, 330-337.

[38] KALAIVANI, T. \& MATHEW, L. 2010. Free radical scavenging activity from leaves of Acacia nilotica (L) Wild. Ex Delile, and Indian medicinal tree. Food and Chemical Toxicology, 48.

[39] KENNEDY, D. O. \& WIGHTMAN, E. L. 2011. Herbal extracts and phytochemicals: plant secondary metabolites and the enhancement of human brain function Advances in nutrition (Bethesda, Md.), 2, 32-50.

[40] KHARKWAL, H., BAHUGUNA, D. P., PANT, M., KHARKWAL, H., KHARKWAL, A. \& JOSHI, D. 2012. Foaming glycosides: A review. IOSR Journal of Pharmacy, 2, 23-28.

[41] KHOO, H. E., AZLAN, A., TANG, S. T. \& LIM, S. M. 2017. Anthocyanidins and anthocyanins: coloured pigments as food, pharmaceutical ingredients, and potential health benefits. Food \& nutrition research, 61, 1361779-1361779.

[42] KNIGHT, J. A. 1995. Diseases related to oxygen-derived free radicals. Annals of clinical and laboratory science, 25, 111-121.

[43] KOYAMA, J., MORITA, I. \& YAMORI, T. 2010. Correlation between cytotoxic activities and reduction potentials of heterocyclic quinones. Molecules (Basel, Switzerland), 15, 6559-6569.

[44] KUMAR, S. \& PANDEY, A. K. 2013. Chemistry and biological activities of flavonoids: an overview. ScientificWorldJournal, $2013,162750$.

[45] KURUTAS, E. B. 2016. The importance of antioxidants which play the role in cellular response against oxidative/nitrosative stress: current state. Nutrition Journal, $15,71-71$.

[46] LEE, D. 2005. Plant pigments and their manipulation. Annual Plant Reviews Vol 12.ssep Davies KM, ed. 2004. Ssep Oxford/Boca Raton: Blackwell Publishing/CRC Press, Boca Raton. $£ 110$ (hardback). 352 pp. Annals of Botany, 96, 1332-1333.

[47] LOBO, V., PATIL, A., PHATAK, A. \& CHANDRA, N. 2010. Free radicals, antioxidants and functional foods: Impact on human health. Pharmacognosy reviews, 4, 118-126.

[48] LOBO, V., PATIL, A., PHATAK, A., CHANDRA, N. 2010. Free radicals, antioxidants and functional foods: Impact on human health. Pharmacognosy, 4, 118126.

[49] LU, J.-J., BAO, J.-L., WU, G.-S., XU, W.-S., HUANG, M.-Q., CHEN, X.-P. \& WANG, Y.-T. 2013. Quinones Derived from Plant Secondary Metabolites as Anticancer Agents. Anti-Cancer Agents in Medicinal Chemistry, 13, 456-463.

[50] MASHOUR, N. H., LIN, G. I. \& FRISHMAN, W. H. 1998. Herbal Medicine for the Treatment of Cardiovascular Disease: Clinical Considerations. Archives of Internal Medicine, 158, 2225-2234.

[51] MGBEAHURUIKE, E. E., YRJÖNEN, T., VUORELA, H. \& HOLM, Y. 2017. Bioactive compounds from medicinal plants: Focus on Piper species. South African Journal of Botany, 112, 54-69.

[52] MIGUEL, M. G. 2018. Betalains in Some Species of the Amaranthaceae Family: A Review. Antioxidants (Basel, Switzerland), 7, 53.

[53] MLAdENKA, P., APPlOVA, L., PATOCKA, J., COSTA, V. M., REMIAO, F., POUROVA, J., MLADENKA, A., KARLICKOVA, J., JAHODAR, L., VOPRSALOVA, M., VARNER, K. J., STERBA, M., TOX, O. E. R., RESEARCHERS, C. H. K. \& COLLABORATORS 2018. A comprehensive review of cardiovascular toxicity of drugs and related agents. Med Res Rev, 38, 1332-1403.

[54] MUSA, M. A., COOPERWOOD, J. S. \& KHAN, M. O. F. 2008. A review of coumarin derivatives in the pharmacotherapy of breast cancer. Current medicinal chemistry, 15, 2664-2679.

[55] OMEDE, A., SUlEIMAN, M. S., ATANU, F. O., SHENENI, V. D. \& JEGEDE, E. R. 2018. Evaluation of Antioxidant and Cytotoxic Properties of Vernonia Amygdalina. International Journal of Plant Studies, 1, 1-6.

[56] OYEDEMI, S. O., OYEDEMI, B. O., IJEH, II, OHANYEREM, P. E., COOPOOSAMY, R. M. \& AIYEGORO, O. A. 2017. Alpha-Amylase Inhibition and Antioxidative Capacity of Some Antidiabetic Plants Used by the Traditional Healers in Southeastern Nigeria. ScientificWorldJournal, $2017,3592491$.

[57] PANCHE, A. N., DIWAN, A. D. \& CHANDRA, S. R. 2016. Flavonoids: an overview. Journal of nutritional science, 5, e47-e47.

[58] PHANIENDRA, A., JESTADI, D. B. \& PERIYASAMY, L. 2015. Free radicals: properties, sources, targets, and their implication in various diseases. Indian journal of clinical biochemistry: IJCB, 30, 11-26.

[59] PICHERSKY, E. \& RAGUSO, R. A. 2018. Why do plants produce so many terpenoid compounds? New Phytol, 220, 692-702.

[60] RE, R., PELLEGRINI, N., PROTEGGENTE, A., PANNALA, A., YANG, M. \& RICE-EVANS, C. 1999. Antioxidant activity applying an improved ABTS radical cation decolourization assay. Free Radical Biology and Medicine, 26, 1231-1237.

[61] RICE-EVANS, C. A., MILlER, N. J., BOLWELL, P. G., BRAMLEY, P. M. \& PRIDHAM, J. B. 1995. The Relative Antioxidant Activities of Plant-Derived Polyphenolic Flavonoids. Free Radical Research, 22, 375-383.

[62] ROA, N. 2003. Bioactive phytochemicals in Indian foods and their potential in health promotion and disease prevention. Asia Pacific Journal of Clinical Nutrition, $12,9-22$.

[63] SAMIDHA, K., VRUSHALI, K. \& VIJAYA, P. 2014. Estimation of Phenolic content, Flavonoid content, Antioxidant and Alpha-amylase Inhibitory Activity of Marketed Polyherbal Formulation. Journal of Applied Pharmaceutical Science 4, 061-065.

[64] SAXENA, M., SAXENA, J., NEMA, R., SINGH, D. \& GUPTA, A. 2013. Phytochemistry of medicinal plants. Journal of Pharmacognosy and Phytochemistry, 1, 168-182.

[65] SAYHAN, H., BEYAZ, S. L. G. \& ÇELIKTAŞ, A. 2017. The Local Anesthetic and Pain Relief Activity of Alkaloids. Alkaloids - Alternatives in Synthesis, Modification and Application.

[66] SHAHIDI, F. \& YEO, J. 2018. Bioactivities of Phenolics by Focusing on Suppression of Chronic Diseases: A Review. International journal of molecular sciences, $19,1573$.

This publication is licensed under Creative Commons Attribution CC BY.

http://dx.doi.org/10.29322/IJSRP.11.10.2021.p11822

WwW.ijsrp.org 


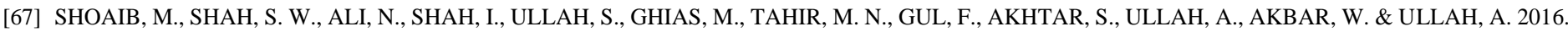
Scientific investigation of crude alkaloids from medicinal plants for the management of pain. BMC Complement Altern Med, $16,178$.

[68] STEIN, O. \& GRANOT, D. 2019. An Overview of Sucrose Synthases in Plants. Frontiers in Plant Science, 10.

[69] STREET, R. A. \& PRINSLOO, G. 2013. Commercially Important Medicinal Plants of South Africa: A Review. Journal of Chemistry, 2013 , 1-16.

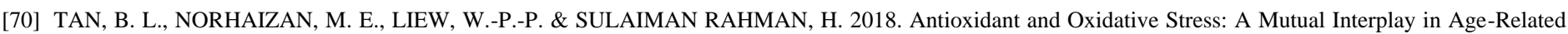
Diseases. Frontiers in Pharmacology, 9.

[71] THACHER, E. A. 1946. Chronic Nasal Obstruction: Its Causes and Treatment. Journal of the American Medical Association, $131,1039-1045$.

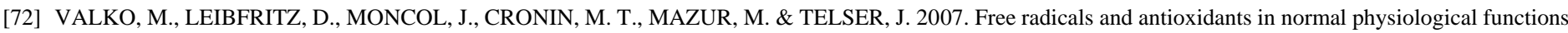
and human disease. The International Journal of Biochemistry and Cell Biology, 39, 44-84.

[73] WAGNER, H. 2000. Bioactive saponins from plants: An update. Studies in Natural Products Chemistry, 21.

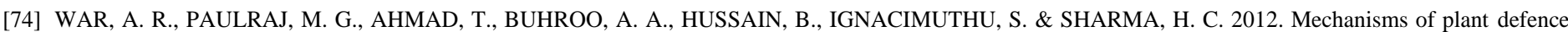
against insect herbivores. Plant signalling \& behaviour, 7, 1306-1320.

[75] WEEKS, A. 2015. The prevention and treatment of postpartum haemorrhage: what do we know, and where do we go to next? BJOG, 122, 202-10.

[76] WINK, M. 2003. Evolution of secondary metabolites from an ecological and molecular phylogenetic perspective. Phytochemistry, 64, 3-19.

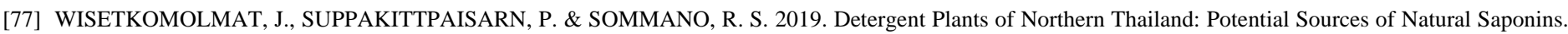
Resources, 8.

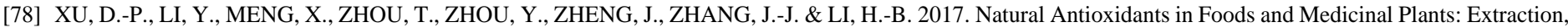
Assessment and Resources. International journal of molecular sciences, 18, 96.

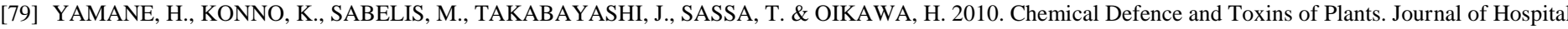
Infection - J HOSP INFECT, 4, 339-385.

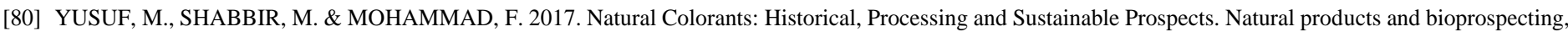
7, 123-145.

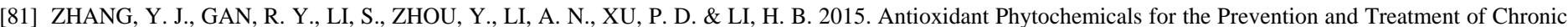
Diseases. Molecules, 20, 21138-21156.

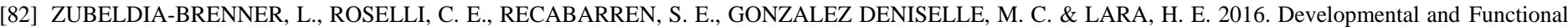
Effects of Steroid Hormones on the Neuroendocrine Axis and Spinal Cord. Journal of neuroendocrinology, 28, 10.1111/jne.12401.

\section{AUTHORS}

First Author - Nkala, B.A, Department of Human Physiology, School of Laboratory Medicine and Medical Sciences, College of Health Sciences, University of KwaZulu-Natal, Durban, 4001, South Africa

Second Author - Mbongwa, H.P, Department of Human Physiology, School of Laboratory Medicine and Medical Sciences, College of Health Sciences, University of KwaZulu-Natal, Durban, 4001, South Africa

Third Author - Qwebani-Ogunleye, T, Institute of Traditional Medicine and Traditional Knowledge, Vaal University of Technology Science and Technology Park, 5 Moshoeshoe Road, Sebokeng, 1911, South Africa.

Corresponding author, Email: bee.nkala81@gmail.com (Nkala, B.A 